\title{
In which journals do family and community physicians in Brazil publish? The Trajetórias MFC project
}

\section{Em que revistas publicam os médicos de família e comunidade no Brasil? O projeto Trajetórias MFC}

\section{¿En qué revistas publican los médicos de familia y comunidad en Brasil? El proyecto Trajetórias MFC}

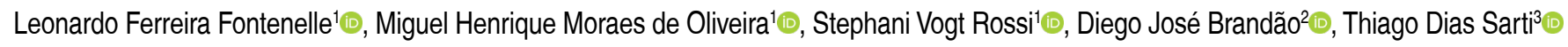

${ }^{1}$ Universidade Vila Velha (UVV), Medical School. Vila Velha, ES, Brazil.

2 Universidade Vila Velha (UVV), Commission of Medical Residency. Vila Velha, ES, Brazil.

${ }^{3}$ Universidade Federal do Espírito Santo (UFES), Center of Health Sciences, Department of Social Medicine. Vitória, ES, Brazil.

\begin{abstract}
Introduction: Authors choose scholarly journals not only to advance their careers but also to interact with their respective scholarly communities. Objective: To describe the journals where family and community physicians in Brazil publish their work. Methods: In late 2018, we compiled a nationwide list of family and community physicians, and downloaded their curricula from the Lattes Platform. We extracted data on their complete journal articles from their curricula, completed these data with queries to CrossRef, VHL/LILACS, and PubMed/MEDLINE, and obtained data on the journals with queries to the United States NLM Catalog. Results: We found 3558 unique articles, published by 1011 journals. The most productive journal was RBMFC (Revista Brasileira de Medicina de Família e Comunidade), which published 347 (9.8\%) of these articles. About one in six articles were published in journals on family practice or primary health care. The proportion of articles published in journals in Brazil decreased during the study period from $83.8 \%$ to $58.4 \%$. Conclusion: As in other countries, family and community physicians in Brazil usually publish in the national journal dedicated to their scholarly community, while also publishing extensively in journals from other disciplines. The increasing proportion of articles published in journals outside Brazil suggests primary care research in Brazil is increasingly of international relevance.
\end{abstract}

Keywords: Periodicals as Topic; Publishing; Family Practice; Community Medicine; Brazil.

How to cite: Fontenelle LF, Oliveira MHM, Rossi SV, Brandão DJ, Sarti TD. In which journals do family and community physicians in Brazil publish? The Trajetórias MFC project. Rev Bras Med Fam Comunidade. 2021;16(43):2589. https://doi.org/10.5712/rbmfc16(43)2589

\author{
Corresponding author: \\ Leonardo Ferreira Fontenelle \\ E-mail: leonardof@leonardof.med.br \\ Funding: \\ No external funding \\ Ethical approval: \\ Report n. 3.033.911, CAAE n. \\ 02957118.2.0000.5064 \\ Provenance: \\ Not commissioned \\ Peer review: \\ External \\ Received: 06/24/2020. \\ Accepted: 01/26/2021. \\ Guest editor: \\ Airton Tetelbom Stein
}




\section{Resumo}

Introdução: Os autores escolhem periódicos acadêmicos não apenas para avançar em suas carreiras, mas também para interagir com suas respectivas comunidades acadêmicas. Objetivo: Descrever as revistas onde médicos de família e comunidade do Brail publicam seus trabalhos. Métodos: No final de 2018, compilamos uma lista nacional de médicos de família e comunidade e baixamos seus currículos da Plataforma Lattes. Extraímos dados de seus artigos completos de periódicos de seus currículos, completamos esses dados com consultas a CrossRef, BVS/LILACS e PubMed/MEDLINE, e obtivemos dados dos periódicos com consultas ao NLM Catalog, dos Estados Unidos. Resultados: foram encontrados 3558 artigos únicos, publicados por 1011 periódicos. O periódico mais produtivo foi a RBMFC (Revista Brasileira de Medicina de Família e Comunidade), que publicou 347 (9,8\%) desses artigos. Cerca de um em cada seis artigos foram publicados em periódicos sobre medicina de família e comunidade ou atenção primária à saúde. A proporção de artigos publicados em periódicos no Brasil diminuiu no período do estudo de $83,8 \%$ para $58,4 \%$. Conclusão: Como em outros países, os médicos de família e comunidade no Brasil costumam publicar em periódico nacional dedicado à sua comunidade acadêmica, ao mesmo tempo que publicam extensivamente em periódicos de outras disciplinas. A crescente proporção de artigos publicados em periódicos fora do Brasil sugere que a pesquisa em atenção primária no Brasil é cada vez mais de relevância internacional.

Palavras-chave: Publicações Periódicas como Assunto; Editoração; Medicina de Família e Comunidade; Medicina Comunitária; Brasil.

\section{Resumen}

Introducción: Los autores eligen revistas académicas no solo para avanzar en sus carreras, sino también para interactuar con sus respectivas comunidades académicas. Objetivo: Describir las revistas donde los médicos de familia y comunidad en Brasil publican su trabajo. Métodos: a fines de 2018, compilamos una lista nacional de médicos de familia y comunidad y descargamos sus currículos de la Plataforma Lattes. Extrajimos datos sobre sus artículos completos de revistas de su currículos, completamos estos datos con consultas a CrossRef, BVS/LILACS y PubMed/ MEDLINE, y obtuvimos datos sobre las revistas con consultas al NLM Catalog, de Estados Unidos. Resultados: se encontraron 3558 artículos únicos, publicados por 1011 revistas. La revista más productiva fue RBMFC (Revista Brasileira de Medicina de Família e Comunidade), que publicó $347(9,8 \%)$ de estos artículos. Aproximadamente uno de cada seis artículos se publicó en revistas de medicina familiar o atención primaria de salud. La proporción de artículos publicados en revistas en Brasil disminuyó durante el período de estudio del 83,8\% al 58,4\%. Conclusión: Al igual que en otros países, los médicos de familia y comunidad en Brasil suelen publicar en la revista nacional dedicada a su comunidad académica, mientras que también publican extensamente en revistas de otras disciplinas. La creciente proporción de artículos publicados en revistas fuera de Brasil sugiere que la investigación en atención primaria en Brasil es cada vez más de relevancia internacional.

Palabras clave: Publicaciones Periódicas como Asunto; Edición; Medicina Familiar y Comunitaria; Medicina Comunitaria; Brasil.

\section{Introduction}

Scholarly journals are essential infrastructure for their respective scholarly disciplines and communities. ${ }^{1-3}$ While publishing in journals with high prestige or impact factor advances the careers of individual researchers, publishing in journals with the right readership communicates the scholarly output to the corresponding scholarly community, thus contributing to its intellectual conversations ${ }^{2-5}$ Family medicine journals are thus strategic for strengthening the capacity for primary care research, ${ }^{6-9}$ which in turn informs primary care and reinforces its status as a scholarly discipline..$^{10-12}$

The status of family medicine or primary care as scholarly disciplines varies substantially across countries. ${ }^{8}$ In Brazil, family and community medicine was recognized as a medical specialty in $1981,{ }^{13}$ but most physicians in primary care are not certified family and community physicians. ${ }^{14}$ Furthermore, research funding and stricto sensu postgraduate education (master's and doctorates) don't recognize family and community medicine or primary care as a scholarly discipline, and few universities have a department dedicated to either. ${ }^{15}$

The lack of recognition of their scholarly discipline might compel family and community physicians in Brazil to engage in "intellectual discussions" (to borrow from Wakeling et al. ${ }^{3}$ ) with neighboring scholarly communities, such as other medical specialties or public health, rather than among themselves. In this study, our objective was to describe the scholarly journals where they publish their scholarly output, as an approach to better understanding the state of primary care research in Brazil. 


\section{Methods}

This was an observational, exploratory study, using administrative data from multiple sources, as part of the Trajetórias MFC project. ${ }^{16}$ Ethical approval was obtained from the research ethics committee in Universidade Vila Velha (certificate 02957118.2.0000.5064), and data on specialist certification was obtained with permission from SBMFC (Sociedade Brasileira de Medicina de Familia e Comunidade, the Brazilian Society on Family and Community Medicine). Three authors (LFF, DJB, and TDS) are family and community physicians and discussed the research project informally with their peers, but no stakeholders were formally included in the study planning.

\section{Data sources}

As previously described, ${ }^{16}$ we compiled the list of family and community physicians in Brazil using data from SisCNRM (Sistema da Comissão Nacional de Residência Médica, the national information system on medical residency) in November 2018 and SBMFC in late December 2018, and obtained their curricula from the Lattes Platform (the national information system on the evaluation of science, technology, and innovation ${ }^{17}$ ), also in late December 2018.

The list of complete journal articles was obtained from the family and community physicians' curricula. During late 2019 through early 2020, we obtained missing DOI (digital object identifiers) from CrossRef using rcrossref 0.9.2, ${ }^{18}$ PubMed identifiers (PMID) from the United States' National Library of Medicine (NLM) through rentrez 1.2.2, ${ }^{19}$ and LILACS identifiers from the Pan American Health Organization's Virtual Health Library (VHL; in Portuguese: Biblioteca Virtual em Saúde, BVS) using httr 1.4.1. We also obtained the corresponding journal titles and ISSN (International Standard Serial Number) from the curricula and then used rentrez in July 2019 to find the corresponding journal records in the NLM Catalog, which is not restricted to journals indexed in PubMed/MEDLINE. ${ }^{20}$ This NLM Catalog lookup was repeated in January 2021 (after this manuscript underwent the first round of peer review), and the statistics were updated accordingly.

Throughout the data acquisition process, all data were extensively verified by three authors (LFF, MHMO and SVR). For example, we made sure every journal was always listed with the same name, consulting when necessary the corresponding journal entries in the NLM Catalog, the ISSN International Center ROAD (Directory of Open Access scholarly Resources) ${ }^{21}$ and the VHL Serials in Health Sciences (SeCS; in Portuguese, Seriados em Ciências da Saúde). We also made sure each journal article had the same LILACS identifier, PMID, and/or DOI when listed more than once, and furthermore considered journal, volume and starting page to identify articles published in collaboration by more than one family and community physician.

We defaulted to trusting data contained in the curricula. For example, we verified the DOI retrieved from CrossRef but not the ones provided in the curricula. Sometimes, however, verifying the internal consistency of programmatically acquired data revealed mistakes in the curricula requiring data editing (for example, wrong page number) or even record removal (for example, journal articles entered more than once by the same author, conference abstracts published in supplements of scholarly journals, or articles published in clearly non-scholarly journals). 


\section{Variables and analysis}

The scholarly output of family and community physicians from Brazil was described using the year of publication and the journals' titles, country, and major subjects. We made these data freely available at Zenodo. ${ }^{22}$ Journal articles were included only if they were published during or after the year of specialization, which was taken to be the year of certification by SBMFC or conclusion of the medical residency, whichever came first. The year of publication was categorized in five-year periods, except for the first period, which included the years 1985 (first included article) through 1998 (last year before the Lattes Platform became online).

The MeSH terms for the journal's major subjects were derived from the corresponding entries from the NLM Catalog. Because the number of major subjects per journal ranged from zero to six, we weighted major subjects by the inverse of their number within a journal. For the sake of simplicity, we did not weight the journal articles by the number or proportion of family and community physicians among the authors.

The description of the most productive (that is, with more included articles) journal titles emphasized those amounting to one-third of the included articles.

\section{Results}

From the 6238 family and community physicians in Brazil as of late December 2018, 4065 (65.2\%) had a curricula in the Lattes Platform. In total, 1111 (17.8\%) had published one or more journal articles, with an average of 4.9 articles per author (median 2, interquartile range [IQR] 1-4). Considering only articles published during or after the year of specialization, $636(10.2 \%)$ of the family and community physicians had published an average of 5.6 articles per author (median 2, IQR 1-4).

Some journal articles appeared in our data more than once, because they had been written in collaboration by more than one family and community physician. After removing these duplicates, there were 3558 unique journal articles. Publication years ranged from 1985 to 2018, with a median of 2012 and an IQR of 2008-2016.

These 3558 unique journal articles were published by 1011 unique scholarly journals. The 14 most productive journals published 1202 (33.8\%) articles by family and community physicians in Brazil (Table 1), while the 846 least productive journals published 1139 (32.0\%). Revista Brasileira de Medicina de Familia e Comunidade (RBMFC) was the most productive journal since its inception in 2004: it published 347 (9.8\%) articles, more than the next three journals combined.

Of the $736(72.8 \%)$ scholarly journals included in the NLM Catalog, 639 (63.2\%) were listed with one or more major subjects, accounting for 2823 (79.3\%) articles. Medicine in general was the most frequent major subject, with general medicine journals having published $467.0(16.5 \%)$ articles by family and community physicians in Brazil (Table 2). Surprisingly, the most productive journal in this category was Revista de APS, which is cataloged as having medicine as its only major subject, rather than primary health care as expected. The next journals in this category were, in order: Revista AMRIGS, Arquivos Catarinenses de Medicina, and PLoS One.

The second most frequent major subject was public health, with 431.4 (15.3\%) articles (Table 2). The most productive journals in the group were Cadernos de Saúde Pública and Ciência \& Saúde Coletiva, followed by Revista de Saúde Pública and Cadernos Saúde Coletiva. 
Table 1. Scholarly journals publishing most articles by family and community physicians in Brazil, up to December 2018

\begin{tabular}{|c|c|c|c|c|c|c|c|c|c|c|c|c|}
\hline \multirow{2}{*}{ Journal } & \multicolumn{2}{|c|}{$1985-1998$} & \multicolumn{2}{|c|}{ 1999-2003 } & \multicolumn{2}{|c|}{ 2004-2008 } & \multicolumn{2}{|c|}{ 2009-2013 } & \multicolumn{2}{|c|}{ 2014-2018 } & \multicolumn{2}{|c|}{ Total } \\
\hline & $\mathbf{n}$ & $\%$ & $\mathbf{n}$ & $\%$ & $\mathbf{n}$ & $\%$ & $\mathbf{n}$ & $\%$ & $\mathbf{n}$ & $\%$ & $\mathbf{n}$ & $\%$ \\
\hline $\begin{array}{l}\text { Revista Brasileira de Medicina de Família } \\
\text { e Comunidade }\end{array}$ & - & - & - & - & 56 & $10.0 \%$ & 114 & $10.5 \%$ & 177 & $11.2 \%$ & 347 & $9.8 \%$ \\
\hline Cadernos de Saúde Pública & 3 & $1.8 \%$ & 13 & $8.1 \%$ & 32 & $5.7 \%$ & 30 & $2.8 \%$ & 35 & $2.2 \%$ & 113 & $3.2 \%$ \\
\hline Revista Brasileira de Educação Médica & 6 & $3.6 \%$ & 2 & $1.2 \%$ & 10 & $1.8 \%$ & 53 & $4.9 \%$ & 42 & $2.7 \%$ & 113 & $3.2 \%$ \\
\hline Ciência \& Saúde Coletiva & 1 & $0.6 \%$ & 2 & $1.2 \%$ & 8 & $1.4 \%$ & 30 & $2.8 \%$ & 63 & $4.0 \%$ & 104 & $2.9 \%$ \\
\hline Revista de Saúde Pública & 10 & $6.0 \%$ & 4 & $2.5 \%$ & 20 & $3.6 \%$ & 26 & $2.4 \%$ & 14 & $0.9 \%$ & 74 & $2.1 \%$ \\
\hline Revista de APS & - & - & 1 & $0.6 \%$ & 23 & $4.1 \%$ & 31 & $2.8 \%$ & 17 & $1.1 \%$ & 72 & $2.0 \%$ \\
\hline Revista AMRIGS & 11 & $6.6 \%$ & 9 & $5.6 \%$ & 17 & $3.0 \%$ & 21 & $1.9 \%$ & 8 & $0.5 \%$ & 66 & $1.9 \%$ \\
\hline Momento \& Perspectivas em Saúde & 38 & $22.8 \%$ & 7 & $4.4 \%$ & 12 & $2.1 \%$ & 8 & $0.7 \%$ & - & - & 65 & $1.8 \%$ \\
\hline Arquivos Catarinenses de Medicina & - & - & - & - & 6 & $1.1 \%$ & 28 & $2.6 \%$ & 29 & $1.8 \%$ & 63 & $1.8 \%$ \\
\hline Interface (Botucatu) & - & - & 1 & $0.6 \%$ & 2 & $0.4 \%$ & 14 & $1.3 \%$ & 35 & $2.2 \%$ & 52 & $1.5 \%$ \\
\hline $\begin{array}{l}\text { Revista da Sociedade Brasileira de } \\
\text { Medicina Tropical }\end{array}$ & - & - & - & - & 17 & $3.0 \%$ & 15 & $1.4 \%$ & 13 & $0.8 \%$ & 45 & $1.3 \%$ \\
\hline Revista HCPA & 18 & $10.8 \%$ & 1 & $0.6 \%$ & 5 & $0.9 \%$ & 6 & $0.6 \%$ & - & - & 30 & $0.8 \%$ \\
\hline Cadernos Saúde Coletiva & - & - & - & - & 8 & $1.4 \%$ & 13 & $1.2 \%$ & 8 & $0.5 \%$ & 29 & $0.8 \%$ \\
\hline Saúde em Debate & 2 & $1.2 \%$ & - & - & 1 & $0.2 \%$ & 8 & $0.7 \%$ & 18 & $1.1 \%$ & 29 & $0.8 \%$ \\
\hline Total & 167 & $4.7 \%$ & 160 & $4.5 \%$ & 562 & $15.8 \%$ & 1090 & $30.6 \%$ & 1579 & $44.4 \%$ & 3558 & $100 \%$ \\
\hline
\end{tabular}

Table 2. Most frequent major subjects of scholarly journals publishing articles by family and community physicians in Brazil, up to 2018

\begin{tabular}{|c|c|c|c|c|c|c|c|c|c|c|c|c|}
\hline \multirow{2}{*}{ Subject } & \multicolumn{2}{|c|}{ 1985-1998 } & \multicolumn{2}{|c|}{ 1999-2003 } & \multicolumn{2}{|c|}{$2004-2008$} & \multicolumn{2}{|c|}{ 2009-2013 } & \multicolumn{2}{|c|}{ 2014-2018 } & \multicolumn{2}{|c|}{ Total } \\
\hline & $\mathbf{n}$ & $\%$ & $\mathbf{n}$ & $\%$ & $\mathbf{n}$ & $\%$ & $\mathbf{n}$ & $\%$ & $\mathbf{n}$ & $\%$ & $\mathbf{n}$ & $\%$ \\
\hline Medicine & 20.3 & $14.5 \%$ & 26.0 & $22.8 \%$ & 79.3 & $16.7 \%$ & 166.0 & $18.3 \%$ & 175.3 & $14.8 \%$ & 467.0 & $16.5 \%$ \\
\hline without Revista de APS & 20.3 & $14.5 \%$ & 25.0 & $21.9 \%$ & 56.3 & $11.9 \%$ & 135.0 & $14.9 \%$ & 158.3 & $13.3 \%$ & 395.0 & $14.0 \%$ \\
\hline Public Health & 15.0 & $10.7 \%$ & 21.0 & $18.4 \%$ & 85.0 & $17.9 \%$ & 133.0 & $14.6 \%$ & 177.4 & $14.9 \%$ & 431.4 & $15.3 \%$ \\
\hline Primary Health Care & - & - & - & - & 56.0 & $11.8 \%$ & 115.0 & $12.7 \%$ & 181.3 & $15.3 \%$ & 352.3 & $12.5 \%$ \\
\hline with Revista de APS & - & - & 1.0 & $0.9 \%$ & 79.0 & $16.7 \%$ & 146.0 & $16.1 \%$ & 198.3 & $16.7 \%$ & 424.3 & $15.0 \%$ \\
\hline Total & 140 & $5.0 \%$ & 114.0 & $4.0 \%$ & 474 & $16.8 \%$ & 908 & $32.2 \%$ & 1187 & $42.0 \%$ & 2823 & $100 \%$ \\
\hline
\end{tabular}

The third most frequent major subject was primary health care, with 352.3 (12.5\%) articles (Table 2). Almost all articles in this group were published in RBMFC, which is cataloged with primary health care as its major subject and family practice as a secondary one. If Revista de APS were included in this group, primary health care would become the second most frequent major subject, ahead of medicine and close to public health.

Combined, medical education and health education accounted for 195.5 (3.5\%) articles (data not shown). Within each major subject, most articles were published by Revista Brasileira de Educação Médica and Interface (Botucatu), respectively.

Family practice was the eleventh most frequent major subject, with $36.2(1.3 \%)$ articles. The main journals were the Annals of Family Medicine and Family Practice (data not shown).

The NLM Catalog-listed journals had their headquarters in 42 different countries. Journals from Brazil published 1996 (66.1\%) of the articles, being followed by journals from England $(357,11.8 \%)$ and the United States $(334,11.1 \%)$. Over time, the proportion of articles published in journals in Brazil dropped from $83.8 \%$ to $58.4 \%$ (Figure 1), while the proportion in journals from other countries rose accordingly. 


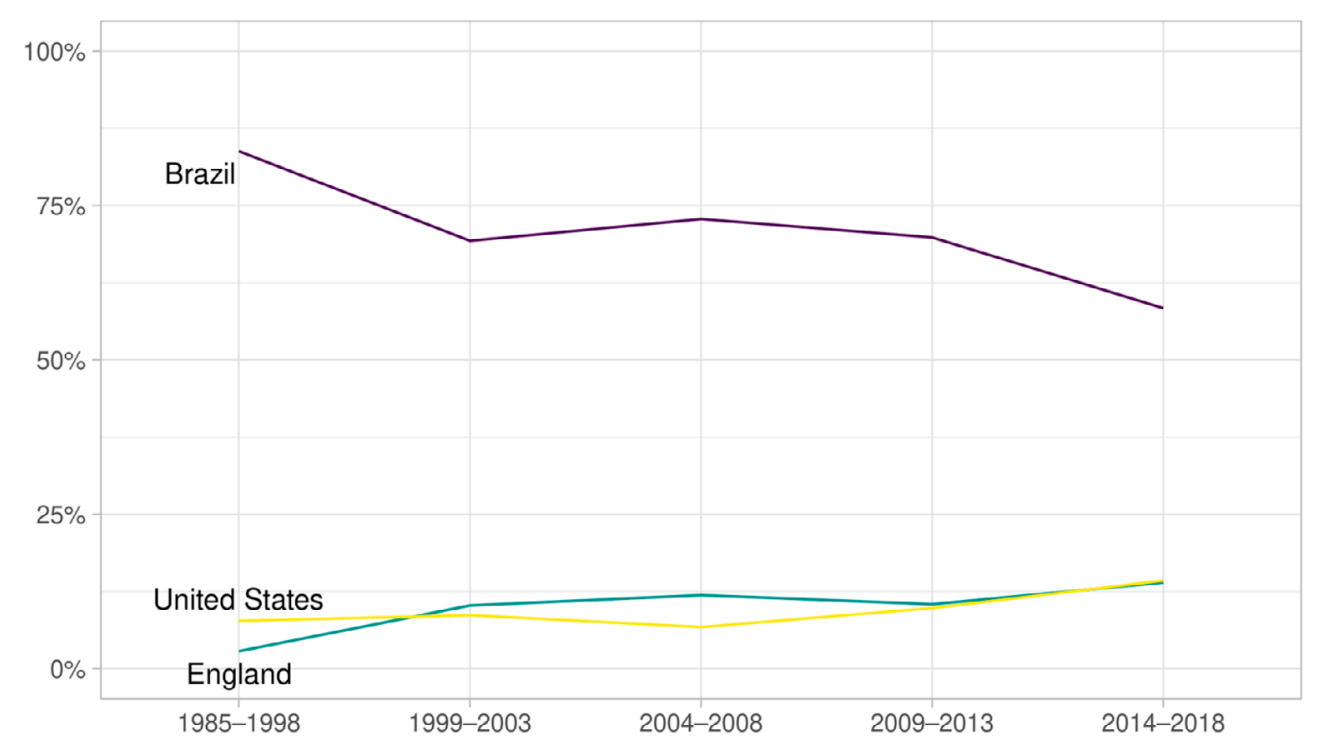

Figure 1. Time trend of publication countries of articles by family and community physicians in Brazil, up to 2018.

\section{Discussion}

As of late December 2018, family and community physicians in Brazil had published their scholarly articles in more than a thousand journals, from tens of countries. Nevertheless, their national disciplinary journal (RBMFC) was also the most prolific one, publishing one in ten of their articles. This might come as a bit of a surprise, because RBMFC has not been favored by traditional journal-level metrics. In Brazil, such metrics are central to the advancement of individual researchers' careers, allocation of research funding, and important administrative decisions about stricto sensu postgraduate programs. In this context, the prominence of RBMFC suggests family and community physicians value the opportunity to engage in intellectual conversations with their own scholarly community. Such preference for national journals dedicated to their scholarly discipline has also been found among family physicians from the United States, ${ }^{23}$ faculty in university departments of family medicine in the United States, ${ }^{24}$ and primary care researchers from Spain. ${ }^{25,26}$ This pattern seems to confirm the importance of national and regional organizations of family medicine maintaining journals to strengthen the scholarly status and research capacity of the discipline. ${ }^{6-9}$

On the other hand, only one in six articles were published in journals about family practice or primary health care (with or without Revista de APS); the other articles were scattered in journals about public health, medicine in general, medical/health education and a myriad of other subjects. This diversity of journal subjects is well documented for family physicians and for faculty in departments of family medicine, at least in the United States. ${ }^{23,24}$ Being at the border of clinical medicine with applied social sciences, ${ }^{27,28}$ family and community medicine has ample opportunity for interdisciplinary research, which might or might not be published in journals about family practice or primary health care. Furthermore, journals of bordering disciplines may be more attractive for career progression because of publishing more basic research and thus having higher journal-level citation metrics. ${ }^{29}$

Although interdisciplinary publication is an international characteristic of family medicine as a scholarly discipline, the Brazilian emphasis on public health deserves further scrutiny. Of the 14 journals accounting for a third of the articles written by family and community physicians from Brazil, six are public 
health journals per the NLM Catalog. One reason might be that these are actually journals about collective health, which in Latin America is a scholarly discipline comprising public health, epidemiology, and human and social sciences in health, ${ }^{30}$ among other definitions. ${ }^{31}$ This wider scope (compared to public health) means collective health frequently includes health research which is not strictly biomedical but would be considered medical research in other contexts.

Another reason might be that most family and community physicians in Brazil earn their master's and Ph.D. degrees in collective health, not medicine. ${ }^{16}$ This prevalence of postgraduate degrees in collective health might explain why, as reported by Almeida et al. ${ }^{28}$ primary care research in Brazil has a focus on healthcare services and policies, instead of clinical research. This focus, in turn, might explain why family and community physicians submit so much research to public health (collective health) journals.

Overall, one-third of the articles were published in journals in other countries, and this proportion seems to be increasing over time. In other words, at least one-third of the scholarly output of family and community physicians in Brazil is of international relevance: otherwise, there would be little reason for foreign journals to publish it. We believe the proportion of internationally relevant articles is even greater, because journals from Brazil may be of international relevance themselves, and individual articles might be internationally relevant even if published in national journals. Moreover, the increasing proportion of articles published in foreign journals suggests primary care research in Brazil is increasingly of international relevance.

Our findings should be interpreted with some limitations in mind, despite deriving from carefully curated data obtained from reliable sources. For instance, consistently with Brazilian norms on medical specialization, we included only physicians concluding the medical residency since 1981 , as well as those undergoing special certification since 2004. When family and community medicine (then "general community medicine") was recognized as a specialty, medical doctors having already concluded their medical residencies, or having experience working as family and community physicians, could not opt to be recognized as such. We can only wonder what scholarly communities do these unacknowledged family and community physicians interact with.

Furthermore, our study was restricted to the scholarly output published in peer-reviewed journals, because of their centrality to the advancement of scholarly disciplines and relative tractability to quantitative analysis. In consequence, our findings might not apply to scholarly communication through other media, such as conferences and textbooks. Furthermore, journal articles are not a direct measurement of knowledge advancement, because not all journal articles contribute equally.

Finally, the temporal context of our data should be considered. First, journal articles were eligible only if published after specialization, to ensure the relevance of the included articles to family and community medicine. The downside is that some of the excluded articles might be relevant, too. Last, our findings are probably overrepresentative of early career researchers, because most family and community physicians concluded their medical residencies or were certificated in the last 10 years ${ }^{16}$ and, as a result, the specialty has a fairly young demographic profile. ${ }^{32}$

The young demographic profile of family and community medicine may constitute an opportunity for its development as an academic discipline. Primary care research has a wide spectrum, and research projects should be adequately distributed along this spectrum for primary care research to fulfill its role in the improvement of primary health care. If the sparsity of clinical research in primary care can be attributed 
to the stricto sensu postgraduate education received by family and community physicians in Brazil, the recently proposed master's degree in family and community medicine ${ }^{15}$ might be pivotal in improving clinical practice in primary health care.

\section{Acknowledgments}

MHMO was supported by a scientific initiation scholarship from Universidade Vila Velha.

\section{Conflicts of interest}

LFF and DJB are board members of Associação Capixaba de Medicina de Família e Comunidade (ACMFC), an organization affiliated to Sociedade Brasileira de Medicina de Família e Comunidade (SBMFC); TDS is a former board member. LFF and TDS are editors-in-chief and DBJ is associate editor of RBMFC, but weren't involved in editorial decisions regarding this manuscript. MHMO and SVR have no competing interests.

\section{Authors' contributions}

Leonardo Ferreira Fontenelle: Conceptualization; Data curation; Investigation; Methodology; Project administration; Software; Supervision; Visualization; Writing - original draft.

Miguel Henrique Moraes de Oliveira: Data curation; Investigation; Writing - original draft.

Stephani Vogt Rossi: Data curation; Writing - review \& editing.

Diego José Brandão: Conceptualization; Methodology; Writing - review \& editing.

Thiago Dias Sarti: Conceptualization; Methodology; Writing - review \& editing.

\section{References}

1. Holmes E. Society publishing: It's all about the community you serve. Learn Publ. 2020;33(1):61-3. https://doi.org/10.1002/leap.1269

2. Vanderstraeten R. Scientific communication: Sociology journals and publication practices. Sociology. 2010;44(3):559-76. https://doi. org/10.1177/0038038510362477

3. Wakeling S, Spezi V, Fry J, Creaser C, Pinfield S, Willett P. Academic communities: The role of journals and open-access mega-journals in scholarly communication. J Doc. 2018;75(1):120-39. https://doi.org/10.1108/JD-05-2018-0067

4. Niles MT, Schimanski LA, McKiernan EC, Alperin JP. Why we publish where we do: Faculty publishing values and their relationship to review, promotion and tenure expectations. PLOS ONE. 2020;15(3):e0228914. https://doi.org/10.1371/journal.pone.0228914

5. McKiernan EC, Schimanski LA, Muñoz Nieves C, Matthias L, Niles MT, Alperin JP. Use of the Journal Impact Factor in academic review, promotion, and tenure evaluations. eLife. 2019;8:e47338. https://doi.org/10.7554/eLife.47338

6. van der Zee J, Kroneman M, Bolíbar B. Conditions for research in general practice. Can the Dutch and British experiences be applied to other countries, for example Spain? Eur J Gen Pract. 2003;9(2):41-7. https://doi.org/10.3109/13814780309160401

7. Mar CD, Askew D. Building Family/General Practice Research Capacity. Ann Fam Med. 2004;2(suppl 2):S35-40. https://doi.org/10.1370/ afm.146

8. Goodyear-Smith F, Mash B. Introduction. In: Goodyear-Smith F, Mash B, editors. International Perspectives on Primary Care Research. Boca Raton: CRC Press; 2016. p. 161-3. (WONCA Family Medicine).

9. Hester CM, Jiang V, Bartlett-Esquilant G, Bazemore A, Carroll JK, DeVoe JE, et al. Supporting Family Medicine Research Capacity:The Critical Role and Current Contributions of US Family Medicine Organizations. Fam Med. 2019;51(2):120-8. https://doi.org/10.22454/ FamMed.2019.318583

10. Maeseneer JMD, Sutter AD. Why Research in Family Medicine? A Superfluous Question. Ann Fam Med. 2004;2(suppl 2):S17-22. https:// doi.org/10.1370/afm.148 
11. MacAuley D. Brazilian Family Medicine and academic excellence. Rev Bras Med Fam Comunidade. 2011;6(20):171-4. https://doi. org/10.5712/rbmfc6(20)403

12. Gotler RS. Unfinished Business: The Role of Research in Family Medicine. Ann Fam Med. 2019;17(1):70-6. https://doi.org/10.1370/ afm.2323

13. Falk JW. A Medicina de Família e Comunidade e sua entidade nacional: histórico e perspectivas. Rev Bras Med Fam Comunidade. 2004;1(1):5-10. https://doi.org/10.5712/rbmfc1(1)2

14. Mash R, Almeida M, Wong WCW, Kumar R, von Pressentin KB. The roles and training of primary care doctors: China, India, Brazil and South Africa. Hum Resour Health. 2015;13(1):93. https://doi.org/10.1186/s12960-015-0090-7

15. Wenceslau LD, Sarti TD, Trindade TG. Reflections and proposals for the establishment of Family and Community Medicine Master's Programs in Brazil. Ciênc Saúde Coletiva. 2020;25(4):1281-92. https://doi.org/10.1590/1413-81232020254.29802019

16. Fontenelle LF, Rossi SV, Oliveira MHM, Brandão DJ, Sarti TD. Postgraduate education among family and community physicians in Brazil: the Trajetórias MFC project. Fam Med Community Health. 2020;8(3):e000321. https://doi.org/10.1136/fmch-2020-000321

17. Lane J. Let's make science metrics more scientific. Nature. 2010;464:488-9. https://doi.org/10.1038/464488a

18. Chamberlain S, Zhu H, Jahn N, Boettiger C, Ram K. rcrossref: Client for Various “CrossRef” "APIs” [Internet]. 2019 [cited 2020]. Available from: https://CRAN.R-project.org/package=rcrossref

19. Winter DJ. rentrez: An R package for the NCBI eUtils API. R J. 2017;9(2):520-6.

20. National Center for Biotechnology Information. NLM Catalog [Internet]. NLM Catalog Help [Internet]. National Center for Biotechnology Information (US); 2019 [cited 2020]. Available from: https://www.ncbi.nlm.nih.gov/books/NBK3799/

21. Cornic N. ROAD: the Directory of Open Access Scholarly Resources to Promote Open Access Worldwide. In: Positioning and power in academic publishing: players, agents and agendas [Internet]. Netherlands: IOS Press; 2016 [cited 2020]. p. 37-41. https://doi. org/10.3233/978-1-61499-649-1-37

22. Fontenelle LF, Oliveira MHM, Rossi SV. Scholarly journals publishing articles by family and community physicians in Brazil, up to December 2018 [Internet]. Zenodo; 2021 [cited 2021]. https://doi.org/10.5281/zenodo.4459429

23. Pathman DE, Viera AJ, Newton WP. Research Published in 2003 by U.S. Family Medicine Authors. J Am Board Fam Med. 2008;21(1):6-16. https://doi.org/10.3122/jabfm.2008.01.070148

24. Liaw W, Petterson S, Jiang V, Bazemore A, Pecsok J, McCorry D, et al. The Scholarly Output of Faculty in Family Medicine Departments. Fam Med. 2019;51(2):103-11. https://doi.org/10.22454/FamMed.2019.536135

25. López-Torres Hidalgo J, Basora Gallisà J, Orozco Beltrán D, Bellón Saameño JÁ. Mapa bibliométrico de la investigación realizada en atención primaria en España durante el periodo 2008-2012. Aten Primaria.2014;46(10):541-8. https://doi.org/10.1016/j.aprim.2014.02.007

26. López-Torres Hidalgo J, Párraga Martínez I, Martín Álvarez R, Tranche Iparraguirre S. Mapa bibliométrico de la investigación realizada en atención primaria en España durante el periodo 2013-2017. Atención Primaria. 2020;52(7):469-76. https://doi.org/10.1016/j. aprim.2019.08.002

27. McWhinney IR. General practice as an academic discipline:Reflections after a visit to the United States. The Lancet. 1966;287(7434):41923. https://doi.org/10.1016/S0140-6736(66)91412-7

28. Almeida M, Gusso G, Trindade TG. Primary care research in Brazil. In: Goodyear-Smith F, Mash B, editors. International Perspectives on Primary Care Research. Boca Raton: CRC Press; 2016. p. 161-3. (WONCA Family Medicine).

29. Peleg R, Shvartzman P. Where Should Family Medicine Papers be Published-Following the Impact Factor? J Am Board Fam Med. 2006;19(6):633-6. https://doi.org/10.3122/jabfm.19.6.633

30. Vieira-da-Silva LM, Pinell P.The genesis of collective health in Brazil. Sociol Health Illn. 2014;36(3):432-46. https://doi.org/10.1111/14679566.12069

31. Osmo A, Schraiber LB. The field of Collective Health: definitions and debates on its constitution. Saúde Soc. 2015;24:205-18. https:// doi.org/10.1590/S0104-12902015S01018

32. Scheffer M, editor. Demografia médica no Brasil 2018. São Paulo: Departamento de Medicina Preventiva da Faculdade de Medicina da USP; Conselho Regional de Medicina do Estado de São Paulo; Conselho Federal de Medicina; 2018. 286 p. 